PRZEGLĄD BIBLIOTECZNY 2020 e-ISSN 2545-2487

\title{
POLISH ACADEMIC LIBRARIES IN THE FACE OF THE COVID-19 PANDEMIC: CRISIS MANAGEMENT AND COMMUNICATION WITHIN THE ORGANISATION
}

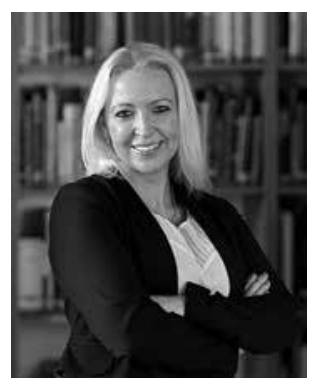

Anna Wałek, dr, Director of the Library of the Gdańsk University of Technology, is an expert in the field of open access to scientific resources, digital libraries as well as organization and management of a scientific library. A graduate of the Institute of Information and Library Science at the University of Wroclaw, where she obtained a PhD in the field of Library and Information Science in 2013. Member of international associations and expert groups. Manager and coordinator of projects implemented from EU funds. Author of scientific publications, in particular about digital libraries, Open Access and innovations in scientific libraries.

KEYWORDS: COVID-19. SARS-CoV2. Coronavirus pandemic. Academic libraries. Remote work. Crisis management. Problem situation management. Risk assessment. Management control. Gdańsk University of Technology Library.

ABSTRACT: Thesis/Objective - The developing SARS-CoV-2 coronavirus pandemic, which was announced in March 2020, has had a significant impact on the activities of universities and their academic libraries. The article aims to present the activities of academic libraries at the time of introducing restrictions on their activities and closing for several months to users and reformulating the services they provide, on the example of the Library of the Gdansk University of Technology (GUT). First of all, attention was paid to how the principles of crisis and 
problem management were introduced at universities. It was also essential to examine how the changes and management decisions were perceived by the library employees who worked according to the new rules in the indicated period. Research methods - The article is based on the analysis of available scientific publications in Polish on crisis management, especially in the era of epidemiological threats. Legal acts and regulations dealing with both crisis management in general and issued in connection with the announcement of the SARS-CoV2 pandemic were also taken into account. The method of survey research based on a questionnaire was also used. The questionnaire was anonymous, provided to the employees of the GUT Library via e-mail. The respondents provided a printout of the questionnaire with answers to the GUT Library Office. Since the survey was addressed only to employees of one institution, it had a limited record. It aimed to collect the respondents' opinions on the work of the GUT Library in the period from March 12 to May 24, 2020, when remote work in special conditions was in force. Results and conclusions - A sudden change in the work mode of the GUT Library itself and its employees, a change in tools and forms of services provided, the need to purchase appropriate equipment and personal protective equipment, the introduction of remote work and other factors became the subject of management decisions made during the emerging crisis. These decisions were in line with the applicable guidelines, both the laws and regulations issued at the national level, as well as the policies and recommendations regarding the functioning of libraries issued by various state institutions and the National Library (book quarantine). However, many of the decisions were individual due to the lack of guidelines and benchmarks on which to base. The reason was also the delayed emergence of procedures. A survey conducted among the employees of the Gdańsk University of Technology Library in May 2020, after the employees returned to stationary work, showed that the adopted solutions were well assessed. The results showed that the adopted solutions had a positive impact on the employees' sense of safety and the work comfort in the period of changing the mode and rules of the Library's functioning.

\section{INTRODUCTION}

The developing SARS-CoV-2 coronavirus pandemic, which was declared in March 2020, has had a significant impact on many aspects and areas of life, activities, and the economy. Among these are also those directly related to the activities of universities and their academic libraries. The sudden reformulation of the work of the library itself and its employees, changes in tools and forms of services provided, the need to purchase appropriate devices and personal protective equipment, the introduction of remote work and other factors became the subject of management decisions that were made during the emerging crisis, in an atmosphere of uncertainty and lack of communication.

It is necessary to settle the issue of definitions at the beginning of this study. The Dictionary of the Polish Language provides the following defi- 
nitions of crisis: 1. "a situation in which a conflict becomes so serious that it threatens an outbreak of war, a change of government or other radical solution"; 2 . "a collapse of the process of economic growth and regression in the economic development of the state"; 3 . "a state of discouragement and loss of motivation to live and work"; 4 . "the disturbance of a system of values or position of something"; 5 . "the most difficult and critical point in the course of a disease" (Dictionary of the Polish Language).

The concept of crisis management is defined, inter alia, by the Act of April 26, 2007, on crisis management: "Crisis management is the activity of public administration bodies that is an element of national security management, which consists of preventing crisis situations, preparing to take control of them through planned actions, responding in the event of crisis situations, removing their effects and restoring critical resources and infrastructure" (Sejm RP, 2020).

An essential element of management control is the assessment of risk that occurs or may occur in the organisation's activities. Risk, as defined in the Encyclopedia of Management, is: "the probability that an economic entity will suffer losses as a result of making a given economic decision. Also, such activity or project in which not all variables are estimated or cannot be estimated on the basis of probability theory. Risk differs from uncertainty in that it deals with repetitive phenomena that are, to some extent, quantifiable. Risk often results from the functioning of a large number of complex and variable entities, the dependencies between them, changes in their environment, limited controllability and the results of these. The main direction of activities of each company should be to limit and reduce risk" (Encyclopedia of Management).

Although libraries are subject to an annual process of management control evaluation, similarly to other university units, no risk factor in the form of an epidemiological threat has appeared in any of the previous reports of the Gdańsk University of Technology Library, or other libraries. This situation will undoubtedly change as a result of the current situation, which has had such a significant impact on the activities of libraries.

On the basis of the definitions mentioned above, it is difficult to unequivocally determine whether the decision-making process related to the reformulation of the rules of library activity in the face of a pandemic is related more to crisis management or risk management, because in both cases specific criteria should be met. While the pandemic itself caused an economic crisis, which is still difficult to define unequivocally, talking about a crisis in libraries resulting from the pandemic constitutes a premature and so far unconfirmed claim. As far as risk management is concerned, after analysing the regulations and other documents relating to the activities of libraries, it turns out that the risk associated with the epidemiological situation was not formulated and no procedures were de- 
veloped. As a consequence of the pandemic and changes that have taken place in the functioning of libraries, it can be stated that this risk has been identified and entered into the catalogue of issues taken into account in monitoring management control.

The situation that was triggered by the coronavirus pandemic can undoubtedly be described as a problematic situation, by recalling and using research and practice related to both crisis management and risk management.

As Regester and Larkin write, "effective management of problem situations and the proper response to them is based on two principles: early identification of the situation and an organised response. Managing problem situations is a proactive, anticipatory and planned process, designed to influence their development before they move to the stage that requires the implementation of risk management techniques" (Regester, Larkin, 2005, pp. 71-72).

The problem situation management model, described by Regester and Larkin, includes six stages:

1. Awareness - corresponding to the first phase of the problem's life cycle; at this stage, the management team should focus on listening and learning - people involved should be alert, open, inquisitive.

2. Exploration - indicating an increase in the urgency and significance of the problem situation, the awareness of the organisation increases, it begins the process of analysis and formulation of opinions - thereupon responsibilities should be divided in their details.

3. Decision making - the organisation needs to think about specific follow-up - the management team should objectively assess options and make decisions, while still stimulating broad thinking and creativity in formulating an action plan.

4. Implementation - requiring that the necessary steps be taken to ensure the effectiveness of management decisions.

5. Fine-tuning - allowing the evaluation of the current activities and their effects in such a way as to introduce improvements to the action plan.

6. Conclusion - key activities at this stage include appropriate delegation of powers and responsibilities and ensuring the implementation of each approved change in the organisation (Regester, Larkin, 2005, pp. 108-111).

Jarosław Marciniak, in the monograph Managing people and work in a crisis situation related to COVID-19 describes the changes resulting from the epidemiological situation and their importance for the management staff. He writes about the pandemic crisis as follows: "A crisis is a condition that threatens the survival of the company, the achievement of its goals, limits the time available for remedial action, and surprises the 
management with its appearance, thus putting the conditions under severe pressure. In view of the risk of coronavirus infection, the most important thing for the company is to care for the health of employees and to follow precautionary rules that minimise the existing threats and allow the organisation to continue functioning. A crisis can be viewed through the prism of serious threats due to the high unpredictability of its consequences" (Marciniak, 2020). As the author further writes: "Crisis situations are such that one day they end: possibly through preventive, interventional, or restorative activities, they cease to be crisis situations". Among the symptoms of a crisis, Marciniak mentions: the feeling of high uncertainty and high risk; the emergence of a very serious threat to the achievement of primary goals and functions; inability to determine the time perspective of difficulties in the operation of the enterprise or organisation; limited reaction time (there is a strong pressure when making decisions and actions, related to time); a tendency to radicalise decisions and the lack of clear guidelines and guidelines for further activity (Marciniak, 2020). All the above-mentioned symptoms have also been identified in the case of the reality of academic libraries. The above definition of crisis and its reference to the current situation have been adopted in this study as a starting point for discussing crisis management in academic libraries during the COVID-19 pandemic.

\section{CRISIS SOLUTIONS AND THEIR APPLICATION}

As Hajkowski and Szewczyk write in an article published on the website of the Polish Economic Society, "The crisis is an emergency situation that got out of hand. (...) It is a series of circumstances/incidents. (...) Observing the current crisis, one gets the wrong impression that the principles of crisis management are being developed on an ongoing basis - as if they never existed before. The pandemic is hitting the foundations of our civilisation. It violates the social and economic order. It paralyses many areas of life. It affects politics, as well as the functioning of public services, including health service. We are witnessing feverish actions by states aimed at minimising the effects of the crisis on citizens. The fight for public health turns into a series of activities aimed at stopping the spread of the virus: quarantine, isolation, and distancing, disturbing the functioning of individuals on the scale of entire societies. (...) Against this background, crisis management appears to be largely responsive, improvised and dependent on the type of crisis and the development of the situation. Nothing could be more wrong. Crisis management begins in times far from a crisis. It means designed and applied prevention aimed at preventing the outbreak of crises and careful preparation for possible crises - if preventive actions 
do not prevent it" (Hajkowski, Szewczyk, 2020). Risk analysis of potential threats should be an introduction to crisis management. The first principle of crisis management, quoted by Hajkowski and Szewczyk, is allocating resources and efforts to combat real threats with an estimated probability of occurrence. The response to less likely threats may be much more modest and based on the general principles of crisis management structures. When you consider the global experience related to epidemic threats, the epidemiological situation as a potential threat should be taken seriously. The authors emphasise that prevention and response to incidents are at the heart of crisis prevention, while knowledge of crisis mechanisms is the foundation of crisis preparedness. A natural continuation of the reception of early warning signals in crisis management is escalation, which builds awareness of the threat and the need for a proportional response, depending on whether we are dealing with an incident, an emergency, or an already formed crisis. In the event of a real crisis, escalation leads to full mobilisation and activation of crisis management structures, the application of previously prepared procedures for dealing with a crisis, and gaining access to resources accumulated in the event of its occurrence (Hajkowski, Szewczyk, 2020). When analysing the signals that reached individual countries, including Poland, one gets the impression that the epidemiological threat was not treated as an object of crisis management. With proper involvement, preventive measures and appropriate decisions could have been taken earlier and their implementation prepared for in line with the principles of crisis management. Crisis management in the final phase focuses on accelerating a return to normalcy at the lowest possible cost.

In the study entitled Management in crisis situations, Witold Lidwa distinguishes the following phases of crisis management:

1. Prevention - actions aiming at the main anticipatory steps eliminating or reducing the possibility of a crisis situation - this refers to activities that eliminate or reduce the probability of a disaster or limit its effects.

2. Preparation - the key element of which is the development of emergency response plans, which describe who will do what and when, with what forces and means and on what legal basis - before, during and immediately after a crisis event. Preparation also includes the provision of specialised capabilities and means of response, such as a command post, crisis communication system, alarm system and crisis response personnel, as well as records of capabilities and resources useful for crisis response.

3. Reacting - which takes place after a real threat or event occurs. The purpose of this is to initiate preventive measures to prevent or minimise the possibility of damage, and after its occurrence, to take res- 
cue actions to provide assistance to the injured and limit secondary damage and losses.

4. Reconstruction - this is the final phase of the crisis management cycle. Rebuilding continues until all systems return to a previous state or better than the previous state. It is divided into short-term and long-term (Lidwa, 2010, pp. 37-38).

An essential task in each of the phases mentioned above is the preparation and application of appropriate tools and procedures. In the case of the situation in Poland and Polish universities, the measures taken depended on the guidelines and recommendations formulated by the Ministry of Health, the Ministry of Science and Higher Education, and the Ministry of Development.

One of the first studies containing guidelines for libraries for the duration of the pandemic was the Guidelines for the functioning of libraries during the COVID-19 epidemic in Poland, which was issued on April 28, 2020 by the Ministry of Development in consultation with the Chief Sanitary Inspector. The objectives of implementing the procedures were defined as: additional enhancement of the security of library (service) staff and users; minimising the risk of infection of (service) employees and users; limiting the number of contacts in the library in a given time period, in order to protect against possible infection; comprehensive anti-epidemic action adjusted to the stage of the epidemic. The guidelines are divided into four parts: 1. Ensuring the safety of employees/staff; 2 . Ensuring security in the facility; 3. Preventive procedures - suspected coronavirus infection of employees/staff; 4. Procedures to be followed in the event of a person/user being suspected of coronavirus infection (Ministry of Development, 2020).

Based on the guidelines of the Ministry of Development, as well as other studies and legal acts issued by the Ministry of Health and the Ministry of Science and Higher Education, internal procedures and regulations for the use of library space and collections were created, both for library users and employees.

\section{REMOTE WORK}

One of the systemic crisis solutions is remote work. This term was introduced under the Act of March 2, 2020 on special solutions related to the prevention, counteraction and combating of COVID-19, other infectious diseases and crises caused by them (Sejm of the Republic of Poland, 2020). Chapter 2 of the Act says that "During the period of the epidemic threat or epidemic state announced due to COVID-19, and within three months after their cancellation, to counteract COVID-19, the employer may order the employee to perform, for a specified period, work specified in the employ- 
ment contract, outside the place of its permanent performance (remote work). (...) Remote work may be recommended if the employee has the technical skills and capabilities to perform such work and if the type of work allows it. (...) At the employer's request, an employee performing remote work is obliged to keep records of performed activities, taking into account, in particular, a description of these activities, as well as the date and time of their performance. The employee draws up a record of the activities performed in the form and with the frequency specified in the order" (Sejm of the Republic of Poland, 2020).

\section{CARE ALLOWANCE}

The Act of March 2, 2020 also introduced another solution aimed at preventing the consequences of a crisis situation, in the form of an additional care allowance. Introduced from March 2020 to June 28, 2020, and then extended, an additional allowance in the amount of $80 \%$ of monthly remuneration for work was given, among other things, in the event of the closure of a nursery, children's club, kindergarten, school or other facility attended by the child, or the inability to provide care by a nanny or day caregiver due to COVID-19 to the insured person released from the obligation to perform work. Many employees caring for children up to the age of 8 , could benefit from this allowance regardless of the regular care allowance or sick leave. Employees who had to undergo quarantine were also entitled to $80 \%$ of the remuneration.

\section{BOOK QUARANTINE}

In the announcement of March 23, 2020, the National Library formulated recommendations for libraries, including dealing with copies of books returned by users.

The following rules of conduct were recommended:

- copies lent for home use should be accepted by personnel wearing latex or nitrile gloves,

- direct contact with the copy prior to its identification should be limited,

- disinfecting returned publications with disinfectants based on detergents and alcohol is not allowed,

- the received copies should be quarantined for a period of 10 days to 2 weeks,

- surfaces in contact with the returned materials should be disinfected by washing with detergent or disinfectants containing at least $60 \%$ alcohol,

- in the event of a confirmed SARS-CoV-2 coronavirus infection among 
employees who come into contact with the collections, it is necessary to quarantine for 10 days to 2 weeks and exclude from using the part of the collections with which the employee had contact.

Exclusion of use (for the period of quarantine) of all copies returned after the end of the library closure period should ensure the safety of the work performed" (National Library, 2020).

In connection with further results of research on the Sars-CoV-2 coronavirus, on May 4, 2020, the National Library changed its recommendation regarding the quarantine period for books and other publications stored in libraries. It was then confirmed that the virus was active for up to 72 hours on plastic surfaces (e.g. book covers, CDs, etc.). However, the recommendations for cardboard and paper on which the virus is active up to 24 hours have not been changed. Other recommendations regarding protection against coronavirus infection remained unchanged. Since, as reported by the National Library, the authors of the studies on the basis of which the recommended quarantine period was shortened urge caution when interpreting their results, it was recommended to extend the quarantine, if possible in the library, and treat as minimal a period of 3 days (National Library, 2020a).

\section{GDAŃSK UNIVERSITY OF TECHNOLOGY LIBRARY - A CASE STUDY}

The beginning of March 2020 in academic libraries was marked by preparation for work in a new formula and a new reality. Although the epidemiological situation was developing dynamically in many European countries, the critical point in Poland occurred on March 4, 2020, with the first diagnosed case of COVID-19. On March 11, 2020, the World Health Organization (WHO) announced a pandemic of the novel SARS-CoV-2 coronavirus. Until then, little action had been taken. The first signals that some restrictions in the functioning of universities might be possible were provided to the managers of libraries a few days before the administrative decision.

Due to the increased risk of infection with the SARS-CoV-2 virus and subsequent COVID-19 cases in Poland, the Minister of Science and Higher Education - following the recommendation of the Government Crisis Management Team - decided to introduce preventive measures to prevent the spread of this virus, and reduce the risk of an epidemic. At that time, the teaching activities conducted by universities supervised by the Ministry of Science and Higher Education were suspended throughout the country.

The Ordinance of the Minister of Health of March 13, 2020, on the declaration of an epidemic in the territory of the Republic of Poland (in $\S 5$ 
section 1 , point 2 and $\S 6$ section 1 , point 1 ) directly concerned the activity of libraries. The regulations, introduced for the duration of the state of epidemic threat in connection with SARS-Cov-2 virus infections, included restrictions on the activities of libraries, archives, museums, and other cultural actions, the restriction of which was a complete prohibition of certain activities. According to the guidelines, libraries could continue work other than direct user services, such as documentation works, preparation of collections, electronic handling of user inquiries, digitisation, or cleaning and selection of books.

On March 11, the Rector of the Gdańsk University of Technology (GUT) issued an ordinance regulating the issues related to the functioning of the university for the period from March 12 to 29, 2020 (later updated). It concerned, among other things, cancellation of classes for undergraduate students, doctoral students and postgraduate students on March 12-29, 2020; recommendations on cancelling events (conferences, symposia, open lectures, arts and other events); suspension of business trips abroad and visits of guests from abroad, as well as cancelling all plans for making the GUT Library available until further notice. In practice, the restrictions were extended for the next months, and thus the library was closed to users until May 24, 2020.

During this period, most of the university employees, including the employees of the GUT Library, were assigned to work remotely.

The first case regarding sending an employee of the GUT Library to work remotely took place in the first week of March 2020. At that time, one of the employees had informed her superiors about her return from vacation in Italy. The decision to send her to work remotely for a period of two weeks was made individually because no procedures had yet been developed that could be used. In many universities, including many units of the Gdańsk University of Technology, the remote work order did not have a unified form or did not exist in practice in any official form. In the GUT Library, immediately after the announcement of the rector's decree on counteracting COVID-19, steps were taken to standardise the rules for assigning employees to remote work. The team consisting of the director of the library and the heads of individual sections developed a procedure for referring an employee to remote work and monitoring the tasks performed by them. Each employee received a written order to work remotely for a period specified in the order (usually a calendar month). Then the immediate supervisor assigned the scope of tasks to be performed to the employee. The employee was obliged to submit reports on the implementation of tasks to the supervisor at the end of each week. Communication between employees took place via e-mail, through online meetings, as well as through business phones, which were partially redirected to cell phones. 
Directors of academic libraries, associated as part of the Conference of Directors of Polish Academic Libraries (KDBASP), exchanged opinions, adopted solutions and encountered difficulties within the KDBASP discussion list.

The information provided by the directors showed that the solutions adopted by the university authorities differed among themselves. Most libraries remained closed, but there were also those that were open to users for the entire period (or for some time), possibly during limited working hours (including the Library of the Silesian University of Technology, the Library of the Leon Schiller National Film School in Łódź, the Library of the Pomeranian Medical University in Szczecin, and the Library of the Warsaw School of Economics).

Depending on the solution adopted at the university, the rules of assigning employees to remote work also differed. In some libraries, all employees were assigned to work remotely, in other libraries some staff remained in so-called readiness (e.g. warehouse employees) due to the fact that they could not perform their typical tasks remotely or worked in rotation or on call. In some libraries, as in the GUT Library, employees were ordered to work remotely (in writing, by e-mail or orally), in others it was on the initiative of an employee who had to submit an appropriate application for the possibility of remote work.

In the GUT Library, the principle was adopted that, as far as possible, all employees should work remotely (except for a few people on one-person duty or performing, for example, warehouse, counter, or cleaning work). In the first days after the announcement of the pandemic, employees who had outstanding vacation leave were also asked to take it. The order to use the outstanding leave by all GUT employees also appeared at a later date in the Circular Letter of the GUT Rector.

By the decision of the university authorities, university-wide and central units, as well as the entire central and faculty administration, resumed stationary work from May 11, 2020. This was the first phase of returning to standard activities. In the period until May 24, 2020, preparatory work for the resumption of service activities was carried out. Procedures were developed and implemented; protective measures were collected, workplaces and schedules were prepared for the return of users.

From May 25, 2020, service activities resumed to a limited extent. Loans and returns became possible again, in accordance with the developed procedures. A reading room for standards and services of the Scientific and Technical Information Section (including the Open Science Competence Centre) was made available. Individual reading rooms, seminar rooms, and independent queries in the Historical Section remained unavailable until September 2020. 
Detailed rules for using the Library, including guidelines on the number of people who can stay in individual rooms at the same time (calculated on the basis of the area and the possibility of maintaining distance), as well as the rules for returning and borrowing books were published on the Library's website and updated on an ongoing basis (GUT Library COVID rules). In October 2020, in all reading rooms, branches, and lending rooms, users are still forbidden to view books on their own, in particular those in open access. All library materials are ordered online or by phone in agreement with a Library employee. Returns are made using a night safe or a self-check device, and in branches that do not have these devices, directly. The books are then sent to quarantine (during the holiday period for 6 days, and since October for 4 days), and also exposed to UV lamps or ozonated in a separate room. A book dispenser (remote locker) was also purchased, which, in the event of the library being closed again, will ensure the continuity of user services; meanwhile, it will allow for non-contact loans from all locations of the GUT Library. All rooms have been marked for, among other things, the number of people who can be in a given area at the same time. The places for users have been marked with regard to their prescribed distance, and disinfectant dispensers have been placed at the entrances to the rooms. Users are required to wear protective masks in the library and follow safety rules.

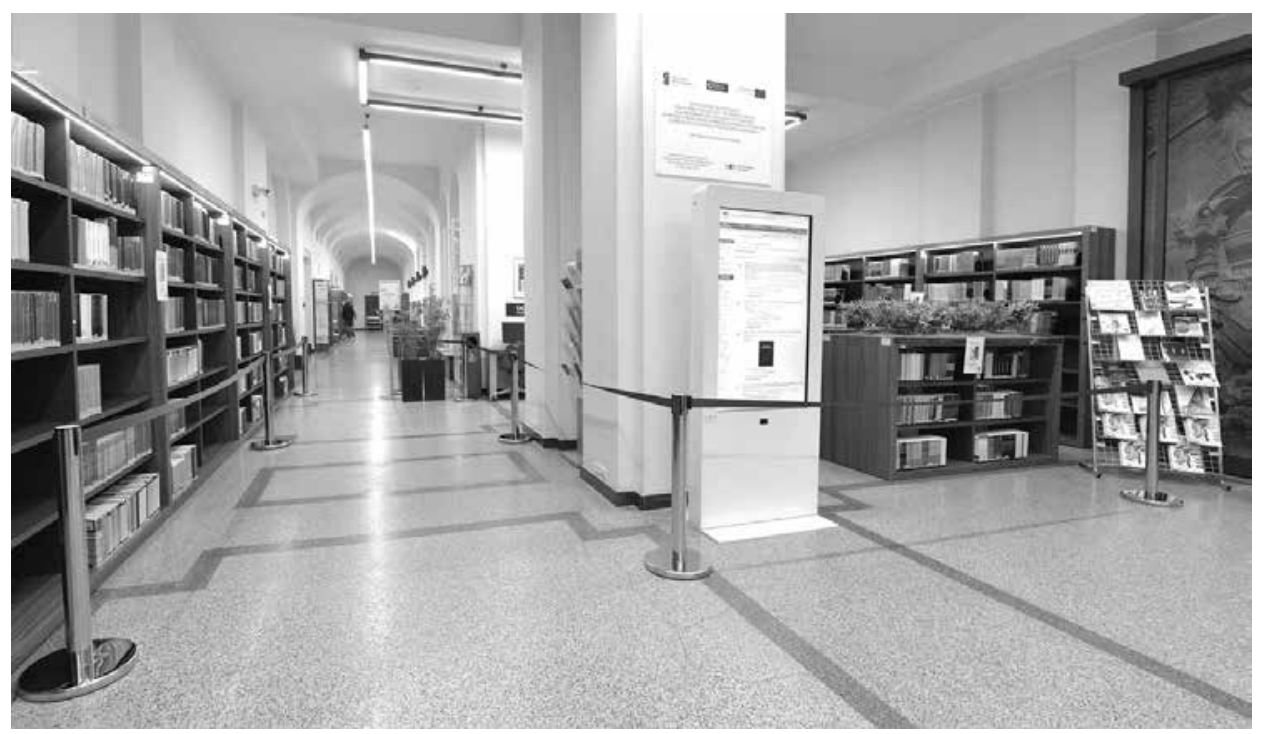

Photo 1 . The main hall of the GUT Library with designated zones inaccessible to users (photo: Tytus Caban) 


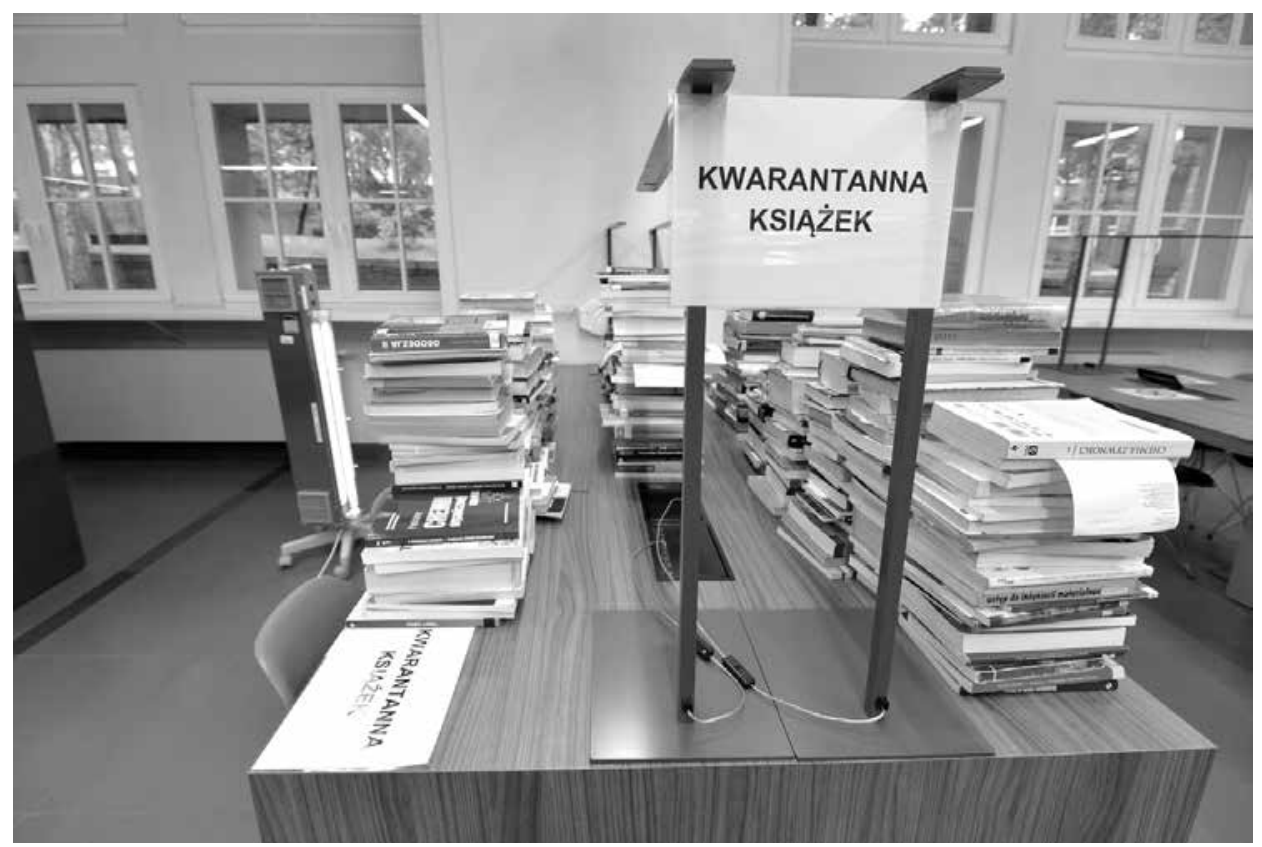

Photo 2. An area in the main reading room of the GUT Library for book quarantine and UV lamp exposure (photo: Tytus Caban)

\section{LIBRARY ACTIVITY DURING REMOTE WORK}

When the Library was closed for users, it began operating with a completely new formula, based primarily on contact via electronic channels, phones, social media and dedicated websites. From the collections process to scientific information and research data management support services, all services have become more virtual. The collections policy at the GUT Library from 2017 has put increasing emphasis on the purchase of electronic sources. The epidemiological situation and the related limitations convinced and in some ways forced the use of e-books also by users who had not been won over so far (in particular, researchers conducting remote classes). They appreciated this type of source, placing more and more orders for the purchase of new titles needed for teaching and research purposes. From March to June 2020, in response to the change in the way the book collection is used, the e-book resources of the GUT Library increased by over 100 new titles. The collection of Polish books was supplemented on the Ibuk Libra platform, and new e-book titles from publishers such as Wiley, Taylor \& Francis have appeared. The ProQuest Ebook Central e-book database was purchased. In the face of the pandemic, many publishers have also decided to make some of their publications, including e-book collections, available to students and researchers free of charge. 
To make it easier for the readers to find these materials, the librarians gathered information about the released resources on the library website. A collection of video courses on the NASBI platform (Scientific Academic Network Internet Library) was also made available.

In response to the limitations resulting from the situation, several new subpages of the GUT Library website were developed and made available, whose main task was to support the academic community in effective remote work. The Remote access to electronic resources of the GUT Library tab contains detailed instructions on how to use electronic sources from home. It contains all the necessary information - a description of logging in to the HAN system, recovering a password to one's library account and the procedure for dealing with a blocked account. The tab also contains the most useful links with access to a wide range of Polish and foreign databases in the fields of technical, economic, natural, social, and human sciences. Reading accounts that were blocked as a result of, for example, arrears in the return of library materials, could be unblocked by phone or e-mail by employees of the Reader Service Section at the Main Library and its branches. Penalties for holding books were suspended from February until the end of September 2020, and all return deadlines were also automatically extended until the end of September 2020.

The widespread movement towards openness, as well as the initiatives of publishers willing to support libraries and scientists themselves in this challenging period, led to the permanent or temporary availability of many e-sources. To organise and popularise these resources, the library staff created a tab Released in remote access, in which initiatives to open scientific resources are collected. Users can find here information about access to special collections, released e-books and e-journals with a lifted access limit, for example to academic textbooks on the Cambridge Core platform, to the De Gruyter and Springer Nature e-book collection, or to a set of educational materials from JSTOR. The tab also included information about free tools for remote work and distance learning, such as free e-learning modules developed by Elsevier Researcher Academy, online training programs from Oxford University Press, and the Science Education module from JoVE.

During the pandemic, libraries have also become an important source of verified and reliable information on the pandemic, its course, and the results of virus research. To provide users with access to reliable sources of knowledge, GUT Library created a subpage containing scientific materials on COVID-19 on it's the website.

As part of a test access, organised by the Library, users were given the opportunity to use resources to which they would not have access on a daily basis. The resources included in the test access differed from those released publicly in that, as in the case of subscription resources, 
they could only be used by authorised persons, in this case, affiliated with the Gdańsk University of Technology. The organisation of the test access was based on a process whereby the Library would request access from the publisher. After obtaining the consent and setting the test date, would configure IP addresses and create unique links in the HAN system, thanks to which users could search for resources remotely from home. In the period from April to May 2020, 10 test accesses were organised at the Gdańsk University of Technology, thus ensuring the possibility of using a total of over 450,000 e-books and journals, as well as conference materials, presentations, dissertations and press releases. Librarians made an effort to select the collections tested so that their subject matter corresponded as much as possible to the scientific interests of the employees of the Gdańsk University of Technology. Resources included sources from disciplines such as physics, engineering, computer science, chemistry, life sciences, but also art and architecture, economics, and finance. Particularly noteworthy is the e-book collection on the Taylor \& Francis platform, containing publications from Routledge, Cogent OA and CRC Press, as well as ProQuest Central - an interdisciplinary platform that brings together the resources of 47 different full-text databases.

In response to the emerging need for education in, among other things, e-learning, the use of sources and the development of other competencies necessary in remote work, a tab was created that includes a constantly updated list of proposed online training, collected in one place and properly grouped. The offer of the training mentioned there is addressed to researchers, librarians, young scientists, and all interested parties. Each training in the tab is free of charge.

The period of seclusion was also a time of increased correspondence and contacts for the employees of the Library using various channels and communicators. The largest group of inquiries were problems with remote access to electronic databases, blocking of a library account, repayment of amounts due for books not delivered on time, an extension of an account's validity, etc. Another group of inquiries covered the issues with publishing in Open Access journals from Elsevier (Science Direct platform) and Springer-Nature (Springer Link platform). Under the national license, researchers affiliated with the institutions covered by this license could choose one of the Creative Commons open licenses for their publication without incurring the costs of the APC (Article Processing Charge). However, it should be remembered that the pool of such articles is limited. Scientists from GUT willingly use this option, but often they are not sure whether they will be charged with the costs of publication or they do not know which license to choose. Clearing up these doubts was an important part of the Library's activities. The third group of inquiries were those in which authors reported problems with linking the profile in the Polish 
Scientific Bibliography with ORCID identifiers and the POL-on system. This obligation was imposed by the provisions of the Law on Higher Education and the regulations implementing it. As early as December 2019, the employees of the Library conducted the first training courses in this area, and the next ones were also held in January and February 2020. Although the epidemiological situation prevented further meetings with scientists, every effort was made to support scientists in this matter.

The activity of the GUT Library in the field of social media at that time was mainly focused on continuing promotional activities on the library's Facebook page, on the two Twitter accounts run by the GUT Library $@$ BibliotekaPG and @BridgeofKnowledge - and on Instagram. A series of Facebook posts have been prepared - in Polish and English - containing information on remote work of the GUT Library, how to share electronic collections, and how to use these collections in the process of preparing diploma theses. Some of the posts on Facebook and Instagram were devoted to the 2020 Libraries Week, this year held under the slogan "Savour the library", and fully transferred to the Internet. A particular set of GUT librarians' reading curiosities was presented on the Facebook library profile, titled: The Kitchen Book in the Background. The original idea of disseminating knowledge about Creative Commons licenses was also introduced, consisting in the preparation of descriptions of individual licenses, accompanied by drawings by Anna Sobala, an employee of one of the GUT Library branches. On Instagram, there is a photo gallery called At the Literary Table, a series of photos showing dishes inspired by literature. Besides, on Twitter were regularly posted tweets with the hashtag \#MOSTWiedzy (\#BRIDGEofKnowledge) related to the promotion of articles by researchers deposited in the MOST Wiedzy Repository. In addition, a series of tweets (39) were prepared to promote datasets produced at universities in Gdańsk (the Gdańsk University of Technology, University of Gdańsk, Gdańsk Medical University), which were deposited on the MOST Wiedzy website, in the "Research data" catalogue.

Moreover, most of the library's employees were intensively trained, using, among others, webinars described in the tab on the website. Employees participating in the work for the MOST Danych (The Bridge of Data) project performed project tasks, including continuing work related to the creation of the database of Polish scientific journals archiving policies. Other duties included cleaning, selection, and inventory verification. The collections were also organised, especially in the branches, by preparing selection protocols and removing duplicates. A lot of work was also done in the field of retroconversion and entering descriptions into the NUKAT database. Many employees were connected remotely to their office computers via remote desktop or were given the ability to access data and tools on their personal computers. 
The Interlibrary Loan was also open to a limited extent: previously borrowed books were returned, and questions about articles appeared. Orders for publications from digital databases were carried out, and - if they were physically available - for journals and fragments of paper books, but the lending of printed books was suspended.

\section{ASSESSMENT OF THE ADOPTED SOLUTIONS AND THEIR IMPLEMENTATION - SURVEY RESULTS}

In May 2020, after the employees of the GUT Library returned to stationary work, a survey was carried out to collect, among other things, their opinions on the organisation of work during the closure of the library, the difficulties encountered, and the assessment of communication channels and effectiveness.

The survey included closed and open-ended questions. In most closed questions, it was also possible to add comments in the appropriate field.

The questionnaire was sent to 60 people, of which 54 respondents replied. The questions and the results were as follows:

1. Has the pandemic situation influenced your sense of security (fear for your health and life, uncertainty about finding yourself in the new reality)?

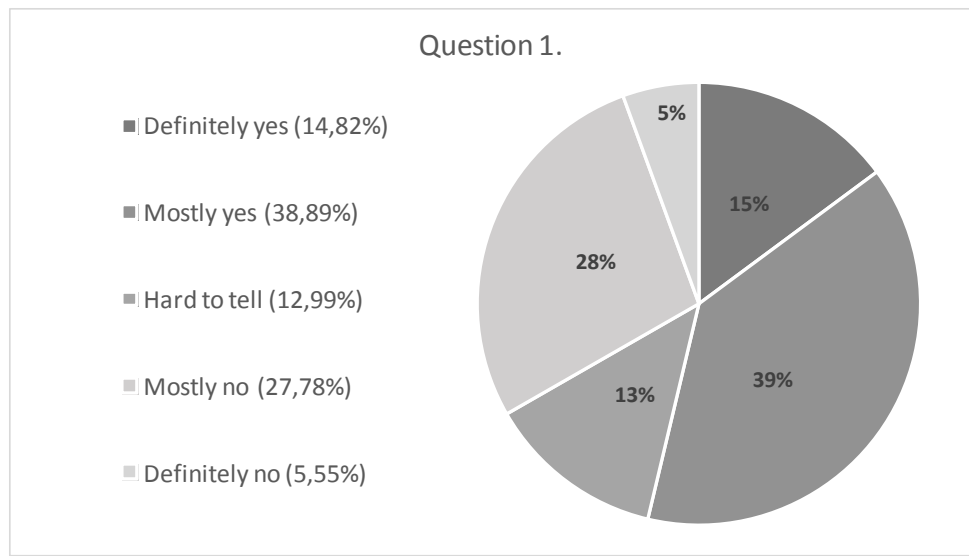

Most of the respondents indicated that they felt threatened or insecure as a result of the pandemic. 
2. Was your job during the pandemic more difficult than before?

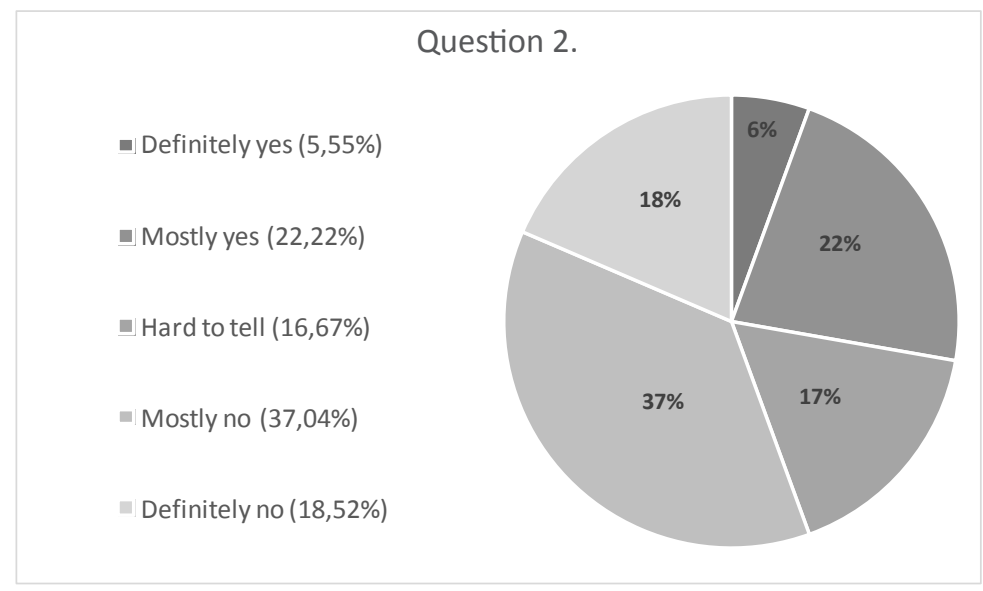

Most of the responses indicated that work during the pandemic was not more difficult than stationary work.

3. Have you taken advantage of the possibility of remote work? If not, what were the reasons?

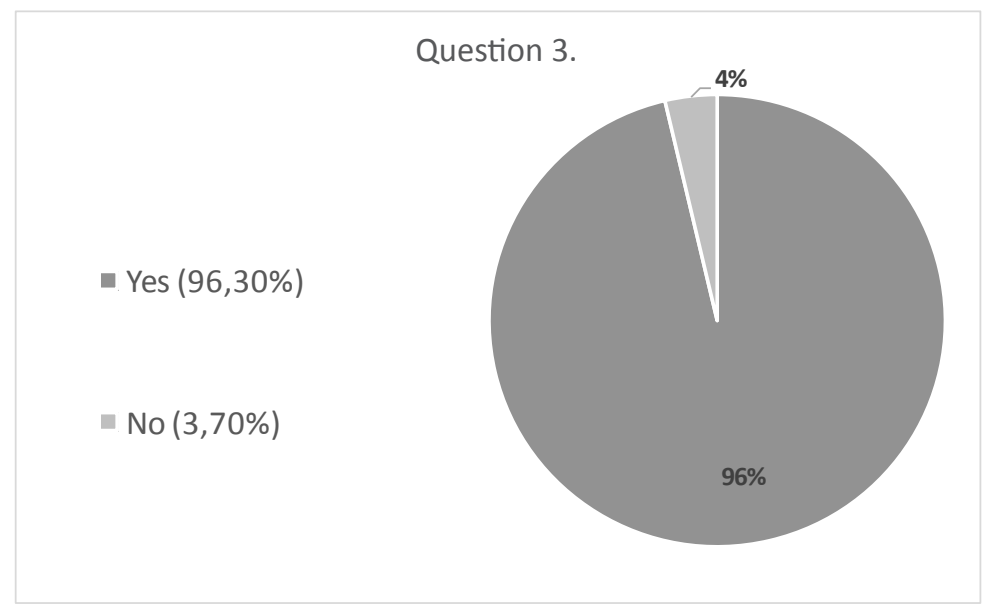

In both questionnaires with a negative answer, the reason was the lack of right working conditions in the place of residence, problems with the Internet connection and/or the lack of computer equipment. 
4. Was the information related to a secondment to remote work communicated precisely and comprehensively?

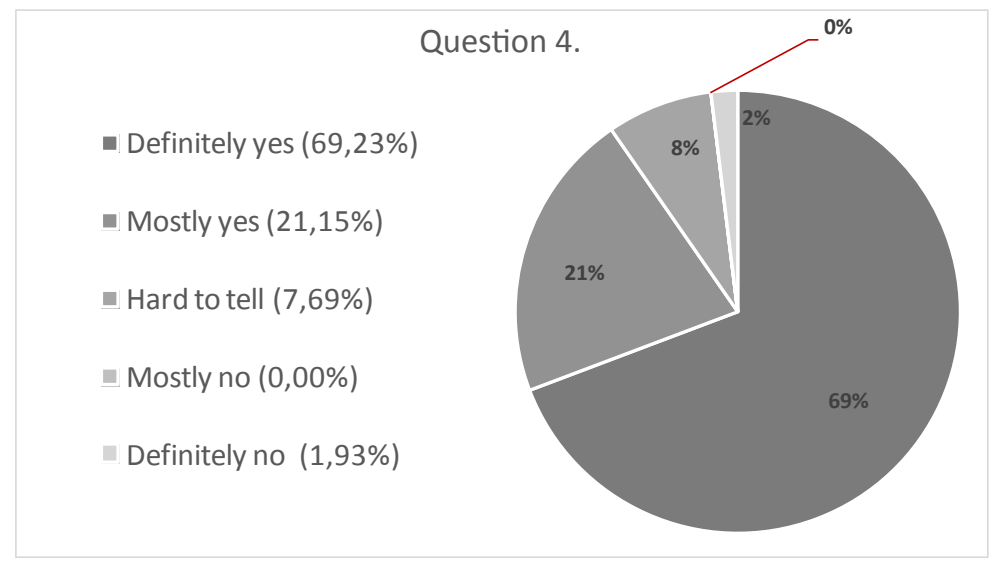

The responses to this question showed that the adopted rules for providing information and instructions proved to be successful and that they were delivered in a precise and understandable manner for the vast majority of employees.

5. Did you have the opportunity to organise a comfortable place to work at home?

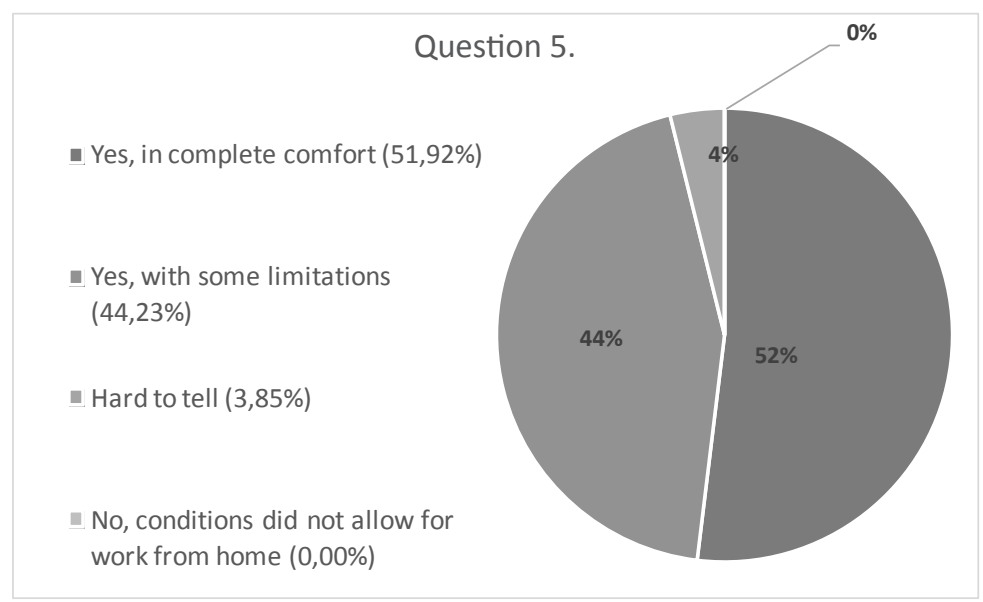

The most frequently reported problems included: the inability to designate a place to work, sharing one computer with a spouse who also worked remotely, combining remote work with childcare, and a limited 
Internet connection. Overall, however, the vast majority of the respondents answered yes to this question.

6. Did you have technical problems while working remotely (e.g. problems with the Internet connection, logging into Moja.PG)? If so, what were they?

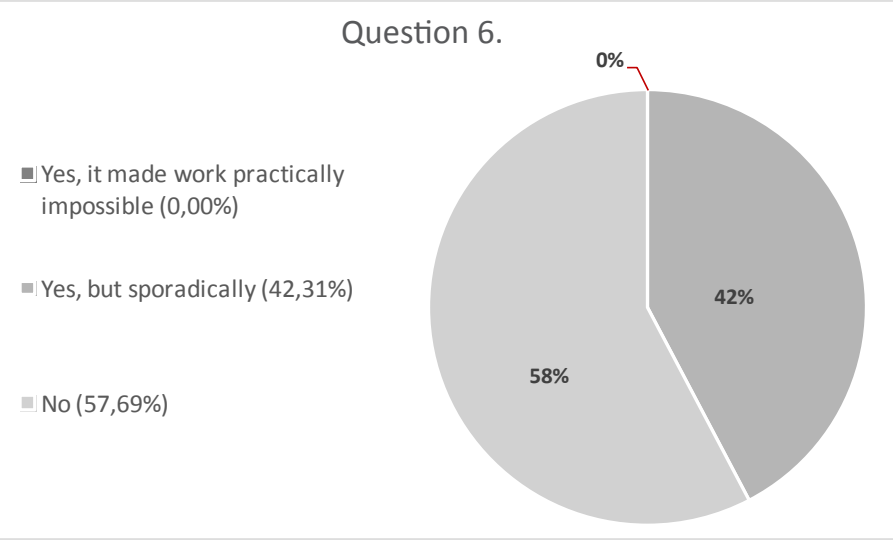

Most of the respondents did not report any significant technical problems while working remotely, with nearly half describing such problems as sporadic. The most frequently reported problems include: too frequent automatic logging out of systems, problems logging on to webinars, quality of the Internet connection, hardware failure or too old equipment. On the other hand, remote access to one's own computer in the Library was positively assessed.

7. How was communication with colleagues?

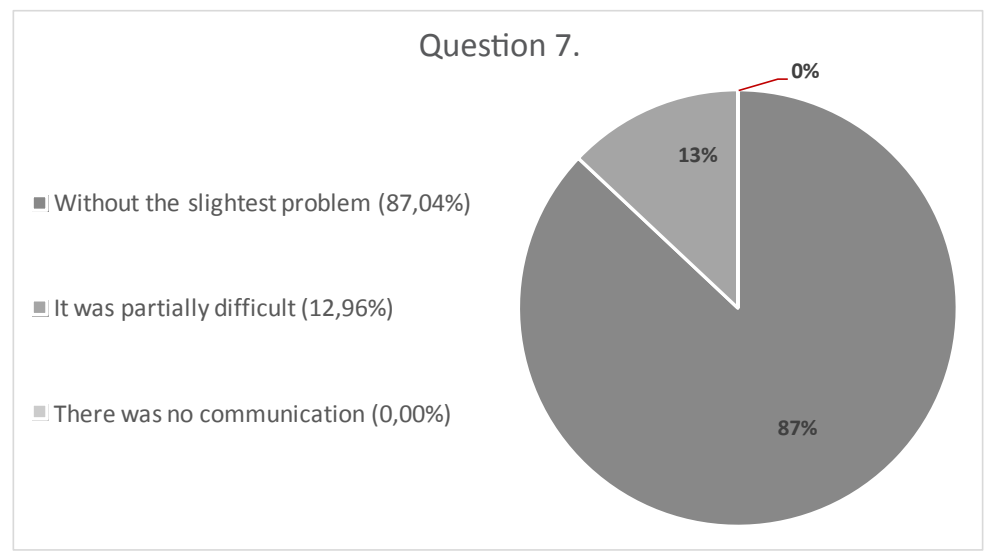


Communication was defined as very good by the respondents. In the first question about communication with colleagues, only seven people replied that it was partially tricky. These difficulties, according to the respondents, resulted from the lack of direct contact and the need to contact via e-mail, telephone or communicators.

8. How was communication with the supervisor?

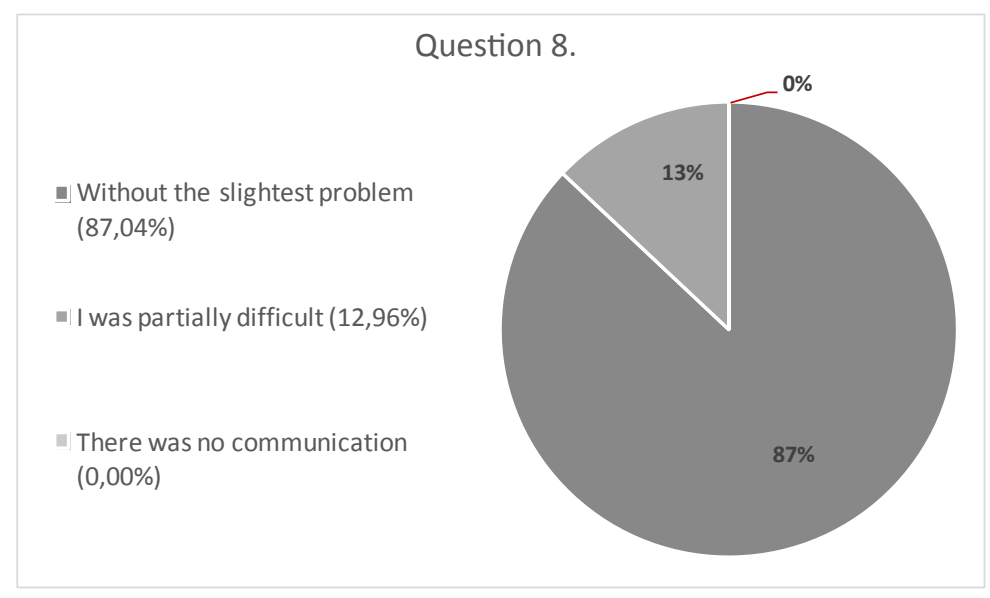

Moreover, communication with the supervisor was assessed as being very good. Only seven people indicated that it was partially tricky. Among the problems, the respondents indicated mainly imprecise commands, as well as a long waiting time for an answer or lack thereof.

9. Was the scope of duties performed during remote work related to the scope of duties performed during stationary work? If not, how much different was it?

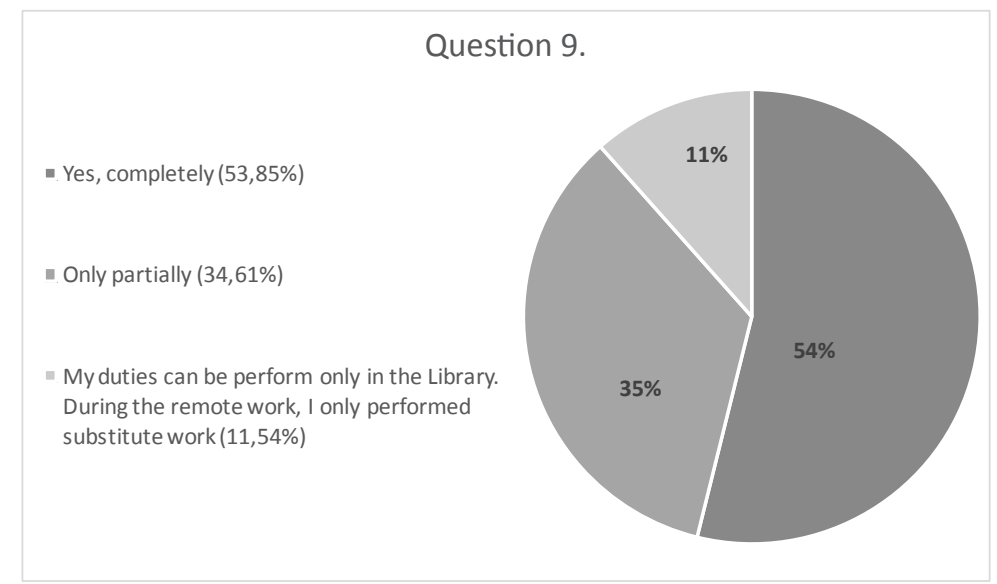


Only 6 respondents indicated that the duties performed while working remotely were substituted and differed from those performed on a daily basis in the library. Others indicated that their tasks were related to the scope performed during stationary work. Twenty-eight people indicated that their duties completely overlapped in both forms of work. The most significant number of respondents indicated problems with access to the resources they use while working in the office. Usually, it was about physical access to the collections. Some employees were delegated to work in a project implemented by the GUT Library (MOST Danych) due to the inability to perform typical duties as part of remote work (e.g. branch employees).

10. Were you on duty at the Library in the period when the Library was closed for external users?

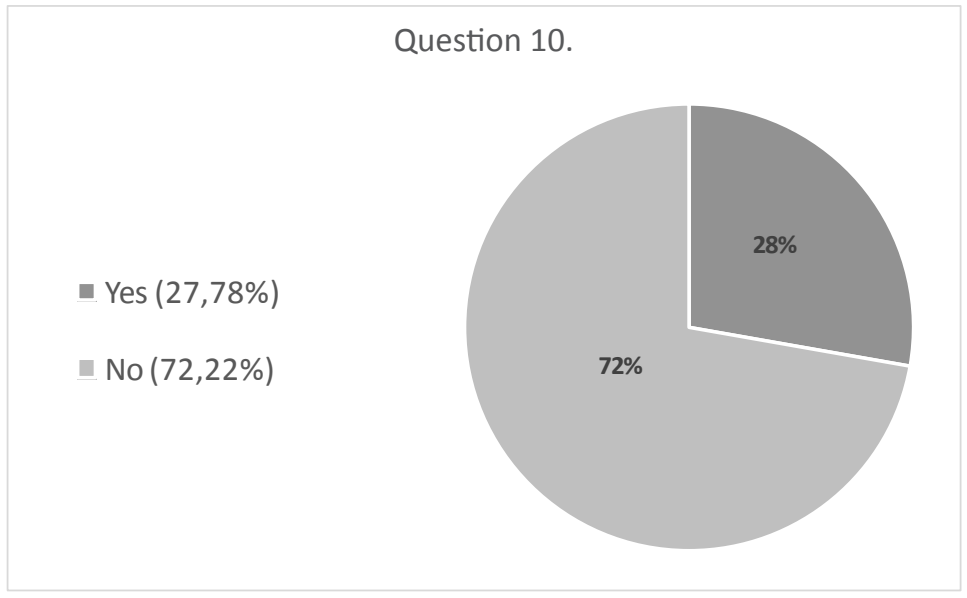

The vast majority of respondents indicated that they performed their duties only remotely, without on-site duty hours.

11. Please list the advantages of remote work in their position of importance from your point of view.

Among the advantages of working remotely, the respondents mentioned:

- Flexibility of working time;

- Higher efficiency;

- Possibility of better focus on the implementation of tasks;

- Time saved on commuting;

- Feeling safe during a pandemic;

- More time to improve their qualifications; 
- Ability to perform overdue tasks, previously postponed "until later";

- Better working conditions - "peace and quiet."

12. Please list the shortcomings that are significant from your point of view, limitations, problems encountered in the provision of remote work for the position you are in:

Among the key disadvantages of such a solution, the respondents indicated:

- Lack of direct contact with colleagues;

- The fact that not all work related to the scope of duties could be performed remotely (no access to the book collection);

- Lack of precise communication;

- Lack of specifically assigned tasks;

- No remote access to their computer;

- Lack of ongoing access to documentation;

- Technical conditions (small monitor, old computer, poor internet connection, no desk);

- Greater consumption of utilities;

- Problem with organising their working time (other distractions);

- Difficult contact with colleagues;

- More tasks to be done than usual;

- Monotony of performed tasks.

13. Have the encountered problems been resolved?

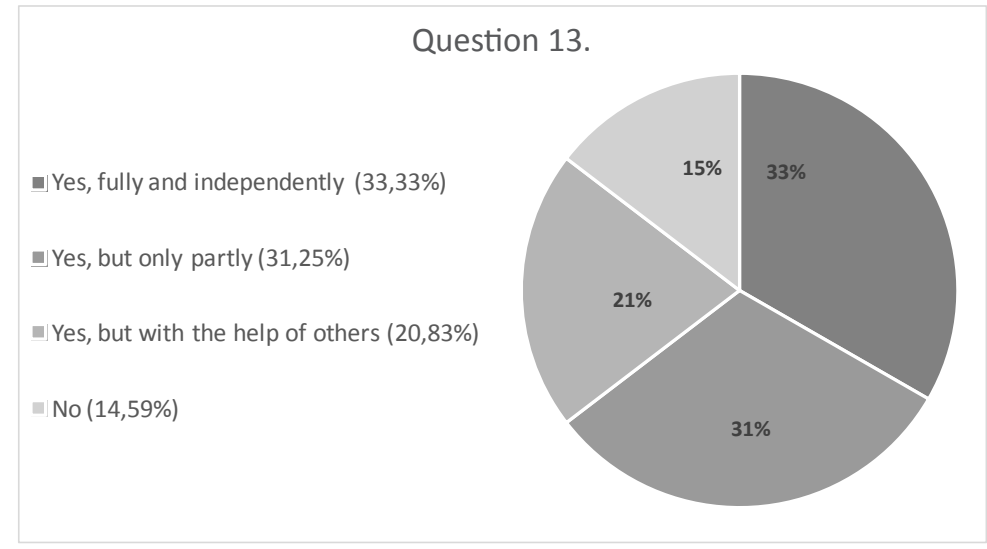

Only seven respondents indicated that the encountered problems could not be solved. In the remaining cases, it was possible in whole or in part, sometimes with the help of other people. Six respondents did not answer this question. 
14. Did you like the possibility of remote work?

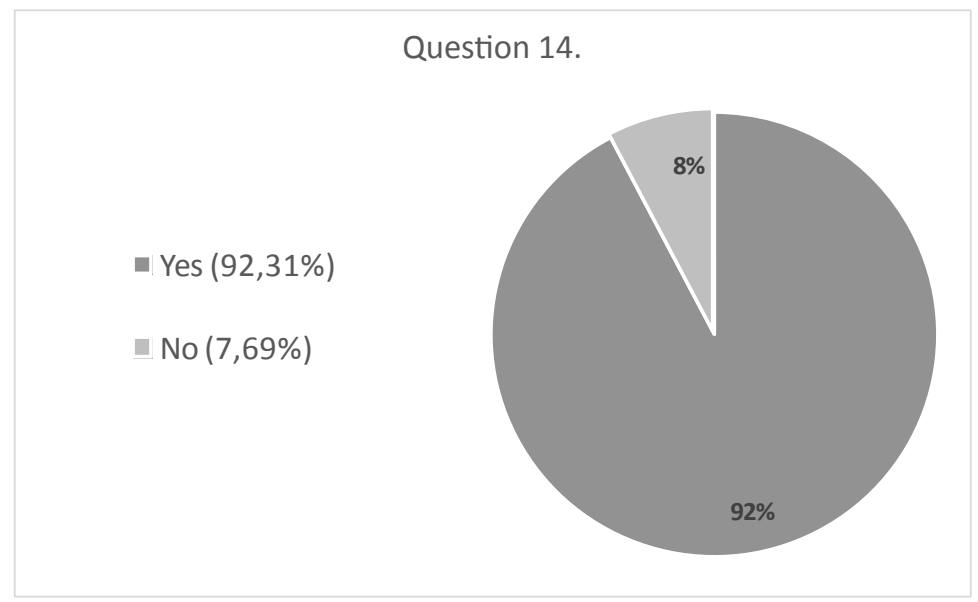

The vast majority of respondents liked the possibility of remote work. Only four people replied that this form did not suit them completely.

15. Would you like to use this form of work in the future, if necessary?

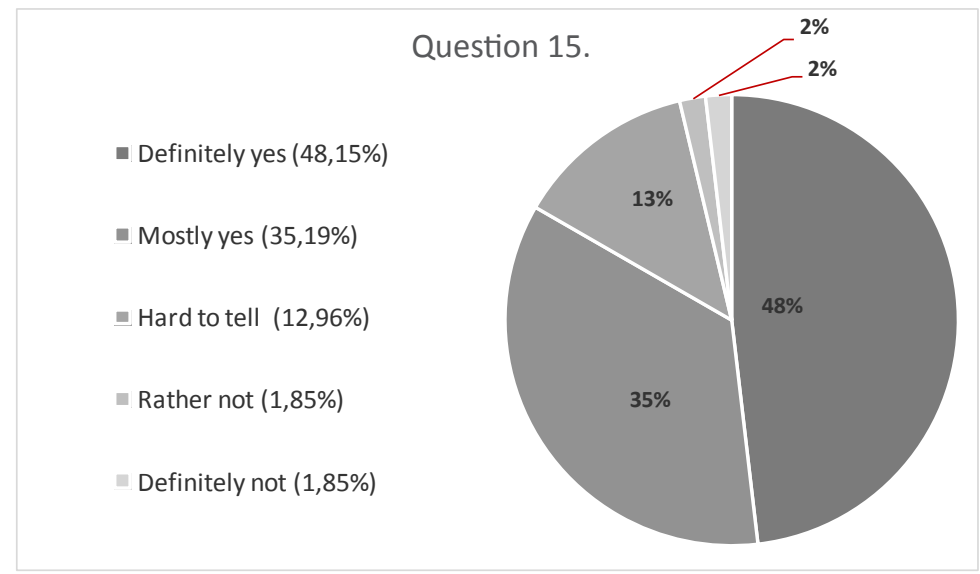

If it was necessary to perform work remotely, the vast majority opted for such a solution (45 people). Only two people replied that they would definitely or rather not want to use such a solution in the future.

16. Do you have any comments and observations about the period of remote work that you would like to share? 
The last open question allowed the collection of general opinions and observations on the period of remote work. Among them were both positive and critical comments. Ultimately, however, this solution was well assessed and well received. Critical remarks included: organisational chaos; lack of ongoing verification of performed tasks; unfair distribution of duties; lack of tools (use of a private telephone, computer). Among the positive comments were, among others, those about opportunities, such as time for training and improving qualifications. Some respondents indicated that during the pandemic they willingly used the on-site "on-call" option because they could not fully perform their duties remotely. Combining remote and stationary work in the future was described as "an ideal situation".

\section{CONCLUSIONS}

The results of the survey showed that most of the adopted solutions were well received by the employees, giving them not only a sense of security but also the possibility of effective use of time for catching up and self-education. An interesting conclusion from the survey was that one of the most critical factors affecting the comfort of work is efficient communication, both between colleagues and with superiors. Taking into account the fact that the situation required rapid adaptation, both on the part of the employer and employees, the actions taken seem justified and accurate. The transfer of the activities of the academic library to the virtual space was a massive challenge for the entire GUT Library team. However, the steps taken turned out to be a reasonably good solution, which is also indicated by reports submitted by employees. The comments to the survey responses included information that employees were disturbed by the fact that the tasks were not always fully verifiable and not always, in their opinion, fairly divided. Based on these comments, it can be concluded that employees need not only transparent and precise instructions but also feedback on the quality of their implementation. This process was positively assessed in most of the responses. Essential elements of the process of commissioning and verifying remote work were weekly reports submitted to managers and then periodically to the library director. In these reports, employees stated, among other things, the number of records created in databases, the scope of thematic works, results in the form of protocols, studies, articles, etc., as well as the titles and topics of training sessions. It was of value not only for the superiors, but also for the employees themselves, who on the one hand indicated this form as being a bit burdensome, but largely motivating. Although there were some obstacles, the employees of the GUT Library were satisfied with the possibility of remote work. The most crucial argument in favour of such a solution tur- 
ned out to be flexible working hours. The biggest obstacle was the lack of direct contact with colleagues, which also showed that the GUT Library team is harmonious and assesses work within the team very well.

\section{SUMMARY}

When considering issues related to the impact of the coronavirus pandemic on academic libraries and their functioning, one should first of all pay attention to how the principles of crisis management were introduced more or less consciously at universities and how the problems of sudden closure and isolation of entire institutions were dealt with. The definitions and diagrams presented in this article in relation to real solutions show that the main problem that arose in this pandemic was too long of a reaction time to warning signals, lack of preparation of institutions for crisis situations, information noise and difficult communication. However, as practice shows, from the example of the Gdańsk University of Technology Library, but also of other academic libraries, these institutions coped quite well in this new, difficult situation. Reformulating their tasks and responding to users' needs on an ongoing basis, especially in the context of access to scientific and teaching materials for distance learning. Although the library might seem to be a unit in which remote work has no chance of complete success, as it turned out, from the example of the GUT Library, the appropriate allocation of tasks and their verification contributed to a specific successful outcome which was not always possible to repeat in other units of the university. The primary functions of academic libraries, i.e., providing scientific and didactic resources, were not wholly suspended as a result of the library closure. The transition to the format of remote services and the organisation of access to additional electronic resources contributed to the positive assessment of the library by the research and teaching staff as well as by students of the Gdańsk University of Technology, expressed, among other ways, in acknowledgements sent by e-mail.

The epidemiological situation showed that it is necessary to implement the principles and tools of crisis management in academic libraries, including the development of diagrams and scenarios of conduct in problematic and critical situations. Among such situations that have not been analysed so far, we must consider not only threats related to the epidemiological situation. It seems advisable to develop rules for dealing with other types of risk as well, even if they are unlikely at the moment. Among them should appear, among others, threats of terrorism and of armed conflict, as well as procedures in the case of, for example, long-term deprivation of media (electricity, Internet), failure of IT systems, a situation in which first aid should be provided to an employee or user, or situations related to another failure or problem. It is puzzling that in recent years routine 
fire alarm tests have even been abandoned in university buildings. Few people also pay attention to and recognise the signals of the alarm siren. The situation in which not only universities and their libraries, but the whole country found themselves showed that more attention should be paid to various key aspects of management, including crisis management.

\section{BIBLIOGRAPHY}

Biblioteka Narodowa (2020) Bezpieczeństwo epidemiczne w bibliotekach [access: 20.08.2020]. Available at: WWW: <https://www.bn.org.pl/aktualnosci/3938bezpieczenstwo-epidemiczne-w\&nbspbibliotekach.html>.

Biblioteka Narodowa (2020) Skrócenie okresu kwarantanny książek w bibliotekach do 3 dni [access: 20.08.2020]. Available at WWW: <https://www.bn.org. pl/aktualnosci/3978-skrocenie-okresu-kwarantanny-ksiazek-w-bibliotekachdo-3-dni.html>.

Biblioteka PG (2020) Zasady funkcjonowania agend Biblioteki PG w czasie COVID-19 [access: 20.08.2020]. Available at WWW: <https://pg.edu.pl/biblioteka-pg/zasady-funkcjonowania-biblioteki-pg>.

Encyklopedia Zarządzania, key word: risk [access: 20.08.2020]. Available at: WWW: <https://mfiles.pl/pl/index.php/Ryzyko>.

Encyklopedia Zarządzania, key word: Crisis management [access: 20.08.2020]. Available at WWW: <https://mfiles.pl/pl/index.php/Zarz\%C4\%85dzanie_kryzysowe>.

Hajkowski Leszek, Szewczyk Jarosław, Koronawirus - zarządzanie kryzysowe to też dziedzina profesjonalnego zarządzania, Polskie Towarzystwo Ekonomiczne. Artykuły i opinie, [access: 20.08.2020]. Available at WWW: <http://www. pte.pl/pliki/2/12/kryzys_hajkowski.pdf>.

Lidwa Witold: Zarządzanie w sytuacjach kryzysowych. Warszawa: Akademia Obrony Narodowej, 2010.

Marciniak Jarosław, Zarządzanie ludźmi i pracą w sytuacji kryzysowej związanej z COVID-19 [e-book] Warszawa: Wolters Kluwer Polska, 2020 [access: 20.08.2020]. Available at: OpenLEX: <https://sip.lex.pl/komentarze-i-publikacje/monografie/zarzadzanie-ludzmi-i-praca-w-sytuacji-kryzysowej-zwiazanej-z-369466779>.

Ministerstwo Rozwoju (2020) Wytyczne dla funkcjonowania bibliotek w trakcie epidemii COVID-19 w Polsce 28.04.2020 [access: 20.08.2020]. Available at WWW: <https://www.gov.pl/web/rozwoj/biblioteki>.

Ministerstwo Zdrowia (2020) Rozporządzenie Ministra Zdrowia z dnia 20 marca 2020 r. w sprawie ogłoszenia na obszarze Rzeczypospolitej Polskiej stanu epidemii [access: 20.08.2020]. Available at WWW: <http://dziennikustaw.gov.pl/ D2020000049101.pdf>.

Ministerstwo Zdrowia (2020a) Rozporządzenie Ministra Zdrowia z dnia 13 marca 2020 r. w sprawie ogłoszenia na obszarze Rzeczypospolitej Polskiej stanu zagrożenia epidemicznego [dostęp: 20.08.2020]. Available at WWW: <http:// dziennikustaw.gov.pl/D2020000043301.pdf>.

MNiSW (2020) Rozporządzenie Ministra Nauki i Szkolnictwa Wyższego z dnia 23 
marca 2020 r. w sprawie czasowego ograniczenia funkcjonowania niektórych podmiotów systemu szkolnictwa wyższego i nauki w związku z zapobieganiem, przeciwdziałaniem i zwalczaniem COVID-19 [access: 07.09.2020]. Available at WWW: <http://dziennikustaw.gov.pl/DU/2020/511>.

MNiSW (2020a) Rozporządzenie Ministra Nauki i Szkolnictwa Wyższego z dnia 11 marca 2020 r. w sprawie czasowego ograniczenia funkcjonowania niektórych podmiotów systemu szkolnictwa wyższego i nauki w związku z zapobieganiem, przeciwdziałaniem i zwalczaniem COVID-19 [access: 07.09.2020]. Available at WWW: <http://dziennikustaw.gov.pl/DU/2020/405 >.

Regester Michael, Larkin Judy, Zarządzanie kryzysem, Warszawa: Polskie Wydawnictwo Ekonomiczne, 2005.

Rektor PG (2020) Zarządzenie Rektora PG z 11 marca 2020 r. w sprawie przeciw działania rozprzestrzenianiu się wirusa COVID-19 wśród społeczności PG [access: 07.09.2020]. Available at WWW: <https://drive.pg.edu.pl/s/N7jWMg7FK8h1CXf $>$.

Sejm RP (2007) USTAWA z dnia 26 kwietnia 2007 r. o zarządzaniu kryzysowym [access: 20.08.2020]. Available at WWW: <http://isap.sejm.gov.pl/isap.nsf/ download.xsp/WDU20070890590/U/D20070590Lj.pdf>.

Sejm RP (2020) Ustawa z dnia 2 marca 2020 r. o szczególnych rozwiązaniach związanych z zapobieganiem, przeciwdziałaniem i zwalczaniem COVID-19, innych chorób zakaźnych oraz wywołanych nimi sytuacji kryzysowych [access: 20.08.2020]. Available at WWW: <http://isap.sejm.gov.pl/isap.nsf/download.xsp/WDU20200000374/ U/D20200374Lj.pdf $>$.

Słownik Języka Polskiego, key word: crisis [access: 20.08.2020]. Available at WWW: <https://sjp.pwn.pl/slowniki/kryzys.html>. 